\title{
PENDEKATAN PEMASARAN DENGAN KONSEP "SIMARK" UNTUK MELESTARIKAN LOCAL WISDOM DI DALAM MASYARAKAT
}

\author{
Fajar Adhitya
}

Fakultas Ekonomi Dan Bisnis Islam UIN Walisongo Semarang

\begin{abstract}
Technologically, online marketing can facilitate the community in fulfilling their life needs. In addition to time efficiency, people also do not have to go all the way to the store to buy the goods they need. However, this can have a negative impact on local wisdom in the community. For that, it needs an effective marketing strategy, both for sellers and buyers without damaging local wisdom in the community. The appropriate strategy in the above context is to use marketing relationship strategy. People who act as sellers can market their products, and people who act as buyers can also buy their needs. In addition, the community can also mutually greet each other in the beautiful silahturahmi, this certainly will not cause a negative impact for local wisdom. That is why, the relationship of marketing is very necessary in business life and society. Marketing by using silahturahmi marketing is similar to marketing strategy within an Islamic perspective marketing which is this time not only by justifying all the ways but also there are rules that limit and regulate the process of marketing or marketing process. With the existence of marketing there must be an underlying business, the business itself aims to gain profitability, survival of a company, social growth, and social responsibility which is done well to achieve the benefit of the people without any harm or harm others.
\end{abstract}

Keywords: Marketing, Marketing Silahturahmi, Local Wisdom

\begin{abstract}
ABSTRAK
Secara teknologi, pemasaran online dapat memudahkan masyarakat dalam memenuhi kebutuhan hidupnya. Selain efisiensi waktu, masyarakat juga tidak perlu jauh-jauh pergi ke toko untuk membeli barang yang dibutuhkannya. Namun, hal ini dapat menimbulkan dampak yang negatif bagi local wisdom di dalam masyarakat. Untuk itu, diperlukan adanya sebuah strategi pemasaran yang efektif, baik bagi penjual maupun pembeli tanpa merusak local wisdom di dalam masyarakat. Strategi yang sesuai dalam konteks di atas adalah dengan menggunakan strategi silaturahmi marketing. Masyarakat yang bertindak sebagai penjual dapat memasarkan produknya, dan masyarakat yang bertindak sebagai pembeli juga dapat membeli kebutuhannya. Selain itu, masyarakat juga dapat saling bertegur sapa dalam indahnya bersilaturahmi, hal ini tentu tidak akan menimbulkan dampak yang negatif bagi local wisdom. Itulah sebabnya, silaturahmi marketing sangat diperlukan dalam kehidupan bisnis maupun bermasyarakat. Pemasaran dengan (SiMark) silaturahmi marketing sama dengan
\end{abstract}


strategi pemasaran dengan perspektif islam yang mana dalam pemasaran kali ini tidak hanya dengan menghalalkan semua cara tetapi juga ada kaidah-kaidah yang membatasi dan mengatur jalannya proses marketing atau pemasaran. Dengan adanya pemsaran pasti ada bisnis yang mendasarinya, bisnis sendiri bertujuan untuk mendapatkan keuntugan, bertahan hidupnya suatu perusahaan, pertumbuhan sosial, dan tanggung jawab soaial yang mana di lakukan secara baik demi mencapai kemaslahatan umat tanpa adanya kemudharatan atau merugikan pihak lain.

Kata kunci : Pemasaran, Silahturahmi Marketing, Lokal Wisdom

\section{Pendahuluan}

Perkembangan jaman telah membawa umat manusia jauh lebih modern dalam berbagai macam aspek kehidupan. Hal ini dapat dilihat dari semakin canggihnya perkembangan teknologi yang ada di berbagai bidang, mulai dari bidang komunikasi, informasi, pendidikan, pertanian, kesehatan, ekonomi, hingga sosial dan budaya. Dalam bidang komunikasi, misalnya, manusia dapat saling mengirimkan pesan dengan mudah meskipun berada dalam jarak yang jauh. Selain itu, pesan yang dapat dikirimkan tidak hanya pesan yang berbentuk teks, tetapi dapat juga mengirimkan pesan dalam bentuk gambar, suara, bahkan video. Online market mampu dipandang mampu mengantikan pertemuan-pertemuan antar pribadi sehingga pertemuan-pertemuan tatap muka bagi sebagian orang dianggap tidak lagi efektif dan efisien karena menghabiskan waktu dan tenaga.

Beberapa masyarakat yang tidak ingin melewatkan perkembangan zaman ini pun mulai memanfaatkan momentum tersebut, yaitu dengan menerapkan kecanggihan teknologi dalam bidang yang ditekuninya. Sebagai salah satu contoh, masyarakat yang berkecimpung dalam bisnis tentunya akan mulai memasarkan produk yang dijualnya dengan memanfaatkan kecanggihan teknologi tersebut. Hal yang dilakukan pebisnis tersebut adalah memasarkan produk-produknya secara online, dengan begitu ia dapat meningkatkan omzet penjualnya kapan saja dan di mana saja tidak terbatas ruang dan waktu, apalagi munculnya kenyataan bahwa keinginan manusia tidak terbatas menjadi peluang tersendiri bagi para pebisnis.

Manusia dalam memenuhi kebutuhan dan keinginan hidupnya tentu tidak akan lepas dari bantuan orang lain, itulah sebabnya mengapa manusia disebut 
sebagai makhuk sosial. Manusia memerlukan suatu barang yang menjadi kebutuhannya perlu melakukan transaksi pembelian dengan penjual sehingga menimbulkan interaksi lanjutan. Seiring dengan masuknya tekhnologi dalam dunia bisnis, khususnya retail menjadikan masyarakat memperoleh kemudahankemudahan dalam usaha memenuhi kebutuhan serta keinginannya, hal tersebut dikarenakan segala sesuatu yang menjadi kebutuhan dan keinginan manusia dapat diakses secara online, mulai dari kebutuhan pangan, papan, maupun sandang. Manusia dapat berbelanja melalui marketplace online, yaitu pasar online yang dapat melayani konsumennya tanpa mengenal batasan waktu dan tempat.

Secara teknologi, hal tersebut memang dapat memudahkan masyarakat dalam memenuhi kebutuhan hidupnya. Selain efisiensi waktu, masyarakat juga tidak perlu jauh-jauh pergi ke toko untuk membeli barang yang dibutuhkannya. Namun, hal ini dapat menimbulkan dampak yang buruk bagi keberlangsungan local wisdom di dalam masyarakat indonesia yang mana budaya lokal sudah ada sejak jaman nenek moyang jauh sebelum bangsa Indonesia merdeka.

Seperti yang kita ketahui bersama bahwa culture budaya bangsa indonesia sangat lekat dengan budaya-budaya daerah atau yang lebih dikenal dengan sebutan adat istiadat daerah. Desakan arus globalisasi dan digitalisasi perlu untuk di batasi supaya tidak mengalir deras mengikis peradaban bangsa ini yang sudah lama melekat di dalam kehidupan masyarakat. Keaneragaman budaya bangsa perlu dilestarikan keberadaannya dan keberlangsungannya, karena budaya merupakan salah satu simbul kekayaan bangsa ini sehingga, diperlukan adanya sebuah strategi maupun pendekatan pemasaran yang efektif, pendekatan pemasaran yang ramah dengan budaya/kearifan lokal baik bagi penjual maupun pembeli tanpa merusak local wisdom di dalam masyarakat.

\section{Kajian dan Pembahasan Teoritis}

1. Silaturahmi

Silaturahmi adalah hubungan timbal balik yang memiliki kekerabatan antar sesama untuk meningkatkan keharmonisan dan kerukunan dalam masyarakat. 
Silaturahmi dapat juga diartikan sebagai suatu komunikasi antar manusia yang dilakukan dengan tujuan untuk mempererat persaudaraan dan mempertebal ikatan batin seseorang terhadap sesama.

Silaturahmi pada dasarnya adalah menjaga hubungan baik dengan sesama manusia, lingkungan, makhluk hidup yang lain, dan tentu saja dengan Allah SWT. Dengan silaturami, manusia melakukan suatu hubungan atas dasar kasih sayang. Silaturahmi adalah kunci dalam melakukan usaha sebagai sarana untuk menuju sumber daya yang tidak terbatas (unlimited resources). Karena dengan silaturahmi, kita akan mampu membentuk komunikasi dua arah dan pada akhirnya akan mampu melakukan identifikasi dan memahami apa yang menjadi kebutuhan dan keinginan pelanggan.

Silaturahmi di dalam konteks bisnis dapat juga dikatakan pemasaran yang berupaya untuk saling menjaga suatu hubungan yang telah terjalin dalam kegiatan bisnis. Rasulullah SAW bersabda, "barang siapa ingin panjang umur dan banyak rezeki, sambungkanlah silaturahmi (H.R Bukhari, Muslim dan Abu Daud)". Dalam konsep silaturahmi marketing diperlukan relationship marketing dimana bentuk komunikasi marketing yang mencakup interpersonal, public relations dan segala bentuk komunikasi lain.

\section{Marketing/Pemasaran}

Apabila terdengar kata pemasaran seringkali dikaitkan oleh banyak pihak dengan penjualan (sales), sales promotion girls, iklan, promosi, atau produk. Bahkan seringkali orang menyamakan profesi marketer (pemasar) dengan sales (penjual). Namun sebenarnya, pemasaran tidaklah sesempit yang diidentikkan oleh banyak orang, karena pemasaran berbeda dengan penjualan. Pemasaran lebih merupakan “suatu seni menjual produk", sehingga pemasaran merupakan proses penjualan yang dimulai dari perancangan produk sampai dengan produk tersebut selesai terjual. Berbeda dengan penjualan yang hanya berkutat pada terjadinya transaksi penjualan barang atau jasa (Al arif,2012:5)

Pemasaran adalah proses sosial dan manajerial di mana seseorang atau sekelompok orang memperoleh apa yang dibutuhkan dan diinginkannya melalui 
penciptaan dan pertukaran produk dan nilai, sedangkan Asosiasi Pemasaran Amerika (AMA) memberikan definisi formal, yaitu pemasaran adalah suatu fungsi organisasi dan seperangkat proses untuk menciptakan, mengkomunikasikan, dan menyerahkan nilai kepada pelanggan dengan cara yang menguntungkan organisasi dan para pemilik sahamnya (Kotler dan Keller, 2012:5). Sehingga secara umum pemasaran dapat diartikan sebagai suatu proses sosial yang merancang dan menawarkan sesuatu yang menjadi kebutuhan dan keinginan dari pelanggan dalam rangka memberikan kepuasan yang optimal kepada pelanggan. (Rivai,2012:6)

Pemasaran dapat diartikan sebagai suatu kegiatan yang mengusahakan agar produk yang dipasarkannya itu dapat diterima dan disenangi oleh pasar (Khasmir,2004:51). Definisi pemasaran menurut Assauri (2013:3) pemasaran adalah hasil prestasi kerja kegiatan usaha yang berkaitan dengan mengalirnya barang dan jasa dari produsen sampai ke konsumen. Dalam pemandangan yang lebih luas, pemasaran adalah proses kegiatan yang mulai jauh sebelum barangbarang/bahan-bahan masuk dalam proses produksi.

American Marketing Assosiation dalam Manajemen Pemasaran Buchari Alma (2011:5) memaparkan pandangan bahwa:

"Marketing is the proses of planning and executing the conception, pricing, promotion and distribution of ideas, goods, services to create exchanges that satisfy individual and organizational goals"

(Pemasaran adalah proses merencanakan konsepsi, harga, promosi dan distribusi ide, barang atau jasa, menciptakan peluang yang memuaskan individu sesuai dengan tujuan organisasi)

\section{Silahturahmi Marketing}

Silahturahmi marketing dengan syariah marketing merupakan bagian yang tidak terpisahkan karena silahturahmi marketing merupakan salah satu cara pemasaran Syariah (Syariah marketing). Syariah marketing adalah sebuah displin bisnis strategi yang mengarahkan proses penciptaan, penawaran dan perubahan value dari suatu inisiator kepada stakeholdernya, yang dalam keseluruhan prosesnya 
sesuai dengan akad dan prinsip-prinsip muamalah (bisnis) dalam Islam (Kertajaya dan Sula, 2006).

Pemasaran Menurut prespektif syariah adalah segala aktifitas yang dijalankan dalam kegiatan bisnis berbentuk kegiatan penciptaan nilai (value creating activities) yang memungkinkan siapapun yang melakukannya bertumbuh serta mendayagunakan kemanfaatannya yang dilandasi atas kejujuran, keadilan, keterbukaan, dan keikhlasan sesuai dengan proses yang berprinsip pada akad bermuamalah islami atau perjanjian transaksi bisnis dalam islam (Abdulah, 2007).

Silahturahmi marketing adalah pemasaran dengan cara memperluas pergaulan, networking dan memperkuat relasi dengan memaksimalkan kekuatan silahturahmi yang agar efektif dipadukan dengan ilmu pemasaran (Gagan,2013). Silaturahmi Marketing adalah munculnya hubungan kekerabatan antar penjual dan pembeli dalam suatu tempat penjualan maupun pembelian, baik itu secara online maupun secara offline yang memiliki tujuan untuk memenuhi kebutuhan bersama.

\section{Definisi Local Wisdom/ Kearifan Lokal}

Kearifan lokal berasal dari dua kata, yaitu local (setempat) dan wisdom (kearifan/kebijakan). Adapun menurut Keraf (2010: 369) bahwa kearifan lokal yang biasa disebut juga kearifan tradisional adalah semua bentuk pengetahuan, keyakinan, pemahaman atau wawasan serta adat kebiasaan atau etika yang menuntun perilaku manusia dalam kehidupan di dalam komunitas ekologis. Jadi kearifan lokal ini bukan hanya menyangkut pengetahuan dan pemahaman masyarakat adat tentang manusia dan bagaimana relasi yang baik di antara manusia, melainkan juga menyangkut pengetahuan, pemahaman dan adat kebiasaan tentang manusia, alam dan bagaimana relasi di antara semua penghuni komunitas ekologis ini harus dibangun. Seluruh kearifan tradisional ini dihayati, dipraktikkan, diajarkan dan diwariskan dari satu generasi ke generasi lain yang sekaligus membentuk pola perilaku manusia sehari-hari, baik terhadap sesama manusia maupun terhadap alam dan Yang Gaib. 
Hal tersebut menunjukkan bahwa:

Pertama, kearifan tradisional adalah milik komunitas. Demikian pula, yang dikenal sebagai pengetahuan tentang manusia, alam dan relasi dalam alam juga milik komunitas. Tidak ada pengetahuan atau kearifan tradisional yang bersifat individual.

Kedua, kearifan tradisional, yang juga berarti pengetahuan tradisional, lebih bersifat praktis, atau "pengetahuan bagaimana". Pengetahuan dan kearifan masyarakat adat adalah pengetahuan bagaimana hidup secara baik dalam komunitas ekologis, sehingga menyangkut bagaimana berhubungan secara baik dengan semua isi alam. Pengetahuan ini juga mencakup bagaimana memperlakukan setiap bagian kehidupan dalam alam sedemikian rupa, baik untuk mempertahankan kehidupan masing-masing spesies maupun untuk mempertahankan seluruh kehidupan di alam itu sendiri. Itu sebabnya, selalu ada berbagai aturan yang sebagian besar dalam bentuk larangan atau tabu tentang bagaimana menjalankan aktivitas kehidupan tertentu di alam ini.

Ketiga, kearifan tradisional bersifat holistik, karena menyangkut pengetahuan dan pemahaman tentang seluruh kehidupan dengan segala relasinya di alam semesta. Alam adalah jaring kehidupan yang lebih luas dari sekedar jumlah keseluruhan bagian yang terpisah satu sama lain. Alam adalah rangkaian relasi yang terkait satu sama lain, sehingga pemahaman dan pengetahuan tentang alam harus merupakan suatu pengetahuan menyeluruh.

Keempat, berdasarkan kearifan tradisional dengan ciri seperti itu, masyarakat adat juga memahami semua aktivitasnya sebagai aktivitas moral. Kegiatan bertani, berburu dan menangkap ikan bukanlah sekedar aktivitas ilmiah berupa penerapan pengetahuan ilmiah tentang dan sesuai dengan alam, yang dituntun oleh prinsip-prinsip dan pemahaman ilmiah yang rasional. Aktivitas tersebut adalah aktivitas moral yang dituntun dan didasarkan pada prinsip atau tabu-tabu moral yang bersumber dari kearifan tradisional.

Kelima, berbeda dengan ilmu pengetahuan Barat yang mengklaim dirinya sebagai universal, kearifan tradisional bersifat lokal, karena terkait dengan tempat yang partikular dan konkret. Kearifan dan pengetahuan tradisional selalu 
menyangkut pribadi manusia yang partikular (komunitas masyarakat adat itu sendiri), alam (di sekitar tempat tinggalnya) dan relasinya dengan alam itu. Tetapi karena manusia dan alam bersifat universal, kearifan dan pengetahuan tradisional dengan tidak direkayasapun menjadi universal pada dirinya sendiri. Kendati tidak memiliki rumusan universal sebagaimana dikenal dalam ilmu pengetahuan modern, kearifan tradisional ternyata ditemukan di semua masyarakat adat atau suku asli di seluruh dunia, dengan substansi yang sama, baik dalam dimensi teknis maupun dalam dimensi moralnya.

Menurut Teezzi, dkk dalam Ridwan (2007:3) mengatakan bahwa "akhir dari sedimentasi kearifan lokal ini akan mewujud menjadi tradisi atau agama". Dalam masyarakat kita, kearifan-kearifan lokal dapat ditemui dalam nyayian, pepatah, sasanti, petuah, semboyan, dan kitab-kitab kuno yang melekat dalam perilaku sehari-hari. Kearifan lokal biasanya tercermin dalam kebiasaan-kebiasaan hidup masyarakat yang telah berlangsung lama. Keberlangsungan kearifan lokal akan tercermin dalam nilai-nilai yang berlaku dalam kelompok masyarakat tertentu. Nilai-nilai itu menjadi pegangan kelompok masyarakat tertentu yang biasanya akan menjadi bagian hidup tak terpisahkan yang dapat diamati melalui sikap dan perilaku mereka sehari-hari.

Ardhana dalam Apriyanto (2008:4) menjelaskan bahwa: menurut perspektif kultural, kearifan lokal adalah berbagai nilai yang diciptakan, dikembangkan dan dipertahankan oleh masyarakat yang menjadi pedoman hidup mereka. Termasuk berbagai mekanisme dan cara untuk bersikap, bertingkah laku dan bertindak yang dituangkan sebagai suatu tatanan sosial. Dari definisi tersebut maka dapat disimpulkan bahwa local wisdom adalah nilai yang dianggap baik dan benar yang telah berlangsung secara kontinyu dan dilakukan oleh masyarakat yang bersangkutan sebagai akibat dari adanya interaksi sosial antara manusia dengan lingkungannya.

\section{Konsep Silaturahmi Marketing}

Pemasaran dengan (SiMark) silaturahmi marketing sama saja dengan strategi pemasaran dengan perspektif islam yang mana dalam pemasaran kali ini tidak 
hanya dengan menghalalkan semua cara tetapi juga ada kaidah-kaidah yang membatasi dan mengatur jalannya proses marketing atau pemasaran. Dengan adanya pemsaran pasti ada bisnis yang mendasarinya, bisnis sendiri bertujuan untuk mendapatkan keuntugan, bertahan hidupnya suatu perusahaan, pertumbuhan sosial, dan tanggung jawab sosial yang mana di lakukan secara baik demi mencapai kemaslahatan umat tanpa adanya kemudharatan atau merugikan pihak lain.

Marketing syariah adalah sebuah proses menawarkan produk kepada calon konsumen/konsumen sesuai dengan prinsip-prinsip syariah, dengan jujur adil, tidak dibuat-buat. Silaturahmi pada dasarnya adalah formula untuk menjaga hubungan baik dengan sesama manusia, lingkungan, makhluk hidup yang lain, dan tentu saja dengan Tuhan, dengan silaturahmi, kita melakukan suatu hubungan atas dasar kasih sayang. Silaturahmi adalah kunci dalam melakukan usaha sebagai saran untuk menuju sumber daya yang tidak terbatas (unlimited resources). Dengan silaturahmi kita mampu membentuk komunikasi secara langsung dan kita dapat mengetahui dan memahami apa saja yang menjadi kebutuhan dan keinginan para pelanggan.

Konsep dagang dengan pendekatan silahturahmi muncul pada abad ke-7. Pada masa tersebut Nabi Muhammad SAW sudah menekankan pada pentingnya silaturahmi dalam rangka mengetahui customer insight dengan menggunakan silaturahmi sebagai salah satu seni dalam berdagang yang tentu saja secara tidak langsung akan menaikkan omzet perdagangan. Dengan silaturahmi kita dapat membangun jaringan kerja (networking) yang tidak terbatas. Silaturahmi memiliki arti dan pengertian yang jauh lebih dalam daripada hanya sebatas hubungan bisnis. Silaturahmi, sebuah sikap dalam menjalin hubungan dengan siapa pun atas dasar jujur, ikhlas, dan professional. (Gunara dkk,2007: 98-99)

\section{Kearifan Lokal (Local Wisdom)}

Pengertian kearifan lokal dalam kamus terdiri dari dua kata: kearifan (wisdom) dan lokal (tempat). Kearifan lokal adalah nilai-nilai kebijaksanaan yang tertanam dalam masyarakat baik desa maupun perkotaan dan mampu menjawab semua 
persoalan yang sedang dihadapi khususnya pada era globalisasi sekarang ini. (Prastyanti, 2017).

Manusia tidak dapat hidup seorang diri, sejak dilahirkan sudah mendapat pertolongan dari orang lain. Mulai tenaga medis dari dokter kandungan, bidan, perawat yang membantu proses persalinan, hingga keluarga. Begitu pula saat manusia memperoleh suatu permasalahan, saat mencari pekerjaan, saat akan berumah tangga/menikah, ternyata perlu bantuan orang lain. Orang-orang yang membantu tersebut merupakan relasi yang harus kita jaga supaya kehidupan mampu berjalan dengan mudah. Sayangnya, banyak di antara kita seringkali lupa bahwa keberhasilan yang didapatkan ada yang ikut andil di dalamnya, apapun bentuknya.

Melihat banyak keberhasilan dari luasnya jaringan yang kita miliki, yang menjadi pertanyaan adalah mengapa kita tidak memaksimalkan relasi yang telah terjalin untuk mencapai kesuksesan-kesuksesan lainnya. Terdapat cara yang mudah yakni dengan menjalankan silaturahmi dengan mereka. Bisa saja, memiliki banyak teman yang sudah lama tidak kita sapa sehingga silaturahmi telah terputus. Padahal, bisa jadi dari teman kita ini ada yang dapat kita jadikan relasi yang berpotensi untuk berkembangnya suatu bisnis.

Dalam konteks tersebut, silaturahmi bisa kita maknai dengan cara untuk menyambung hubungan, baik dengan teman yang telah terputus maupun yang belum berhubungan. Semakin banyak teman akan memudahkan kita dalam menjalani kehidupan. Hal ini sejalan dengan sebuah hadits, yang artinya "Jika kamu beriman kepada Allah dan hari akhir, maka sambunglah tali silaturahmi.",

Silaturahmi pada dasarnya adalah formula untuk menjaga hubungan baik dengan sesama manusia, lingkungan, makhluk hidup yang lain, dan tentu saja dengan Allah SWT. Dengan silaturami, manusia melakukan suatu hubungan atas dasar kasih sayang. 
Selanjutnya Gartika (2013) mengemukakan bahwa silaturahmi marketing dapat mempengaruhi keberhasilan bisnis serta keberlangsungannya dalam waktu yang lama dan menambah rezeki dengan:

1. Memperluas pertemanan, memperkuat relasi, dan memberdayakan konsumen dari mulut ke mulut

2. Memastikan kesuksesan melalui hukum kelimpahan silaturahmi dengan kejujuran, keikhlasan, profesionalisme, dan saling menolong

3. Memberikan tujuan, memiliki nilai dan segmentasi

4. Mengundang konsumen melalui kursus, pelatihan, seminar, serta demo produk dan kunjungan pabrik.

5. Memperluas cabang usaha, menjadikan bisnis waralaba, membuka pasar baru

6. Memanfaatkan tempat orang berkumpul (keamaian), bisa berbentuk event, pameran, ajang musik, tabligh akbar, komunitas, hobi, perkumpulan, asosiasi, organisasi, dll

7. Menembus pasar yang sulit sekalipun dengan mediasi silaturahmi

8. Memelihara mindset silaturahmi agar networking semakin berkembang.

Sebenarnya, silaturahmi marketing telah lama berkembang di dalam masyarakat, yaitu sejak zaman Rasulullah SAW, hanya saja di era globalisasi seperti sekarang ini budaya silaturahmi semakin terkikis oleh perkembangan zaman. Syariat menyuruh supaya kita selalu menyambung dan menjaga hubungan kerabat (shilah ar-rahim). Sebaliknya, syariat melarang untuk memutuskan silaturahim.

Peran Silaturahmi Marketing bagi Local Wisdom di dalam Masyarakat Perkembangan teknologi informasi yang berkembang sangat pesat saat ini berpengaruh bagi masyarakat dalam mendukung berbagai kegiatan bisnis baik besar maupun kecil agar dapat dikenal secara global. Dengan adanya perkembangan teknologi informasi saat ini telah mengubah kebudayaan sebagian besar masyarakat dunia, baik yang tinggal di perkotaan maupun pedesaan (Irianto,2016:214). 
Seseorang tidak dapat memenuhi kebutuhan hidup/keinginannya, kecuali bermitra dengan lembaga atau orang lain. Silaturahmi marketing ini erat sekali hubungannya dengan spiritualisasi marketing, di mana dalam spiritualisasi marketing, marketing dirancang berdasarkan tiga kombinasi penting: pertama, pemasaran pada tingkat kecerdasan intelektual, fokusnya adalah strategi, program (product, place, price, promotion, marketing mix), diferensiasi, dan selling. Kedua, pemasaran pada tingkat kecerdasan emosional/rasa ditandai dengan hadirnya konsep customer relationship, emotional branding, dan experiental marketing yang intinya adalah memasukkan value emosional untuk memanjakan pelanggan dengan cinta yang menciptakan pengalaman-pengalaman baru dalam mengkonsumsi produk. Ketiga, pemasaran pada level kecerdasan spiritual, yaitu pemasaran yang di landasi oleh nilai-nilai akidah yaitu kejujuran, amanah (kredibel, tanggung jawab), fathanah (cerdas dan bijaksana), tabligh (komunikatif), dan sebagainya (disebut soul marketing) yang telah dicontohkan dan disabdakan oleh Rasulullah SAW. Pemasaran spritual mendorong marketer agar menjadikan kegiatan pemasaran itu sebagai ibadah untuk menciptakan kemakmuran dan dakwah fastabiqul khairah.

Berdasarkan konsep spiritul marketing di atas, maka silaturahmi marketing dapat digolongkan ke dalam kombinasi yang kedua, di mana pada kombinasi kedua tersebut menjelaskan bahwa konsep pemasaran adalah tentang bagaimana menciptakan emosial atau rasa kepada si pembeli dengan customer relationship. Customer relationship merupakan hubungan yang terjalin dari si penjual dengan pembeli. Hubungan ini sangat penting untuk diwujudkan dalam sebuah strategi pemasaran, karena dengan terciptanya hubungan tersebut maka akan menimbulkan rasa nyaman bagi si pembeli. Hal ini seterusnya akan berdampak positif pada penjualan.

Silaturahmi marketing juga tidak hanya berdampak positif pada omzet penjualan saja, tetapi berdampak positif pula pada kearifan lokal atau yang biasa dikenal dengan local wisdom di dalam masyarakat, hal tersebut dikarenakan dengan bersilaturahmi maka artinya antara penjual dan pembeli akan saling bertemu dan bertatap muka secara langsung. Berbeda dengan jika si pembeli 
berbelanja online. Bertemunya penjual dan pembeli inilah yang akan meningkatkan nilai sosialisme dalam suatu masyarakat, dan nilai sosialisme tersebut sangat berpengaruh bagi terjaganya local wisdom.

Silaturahmi marketing dapat dilakukan dengan berbagai macam cara, salah satunya yaitu dengan membawa produk jualan ke acara-acara yang akan dihadiri. Sebagai contoh, ketika di dalam masyarakat akan diadakan suatu kegiatan PKK di lingkungan masyarakat desa, maka hal ini sangat cocok bagi penjual fashion hijab untuk memasarkan produknya. Dalam kegiatan tersebut tentunya akan dihadiri oleh muslimah yang berpakaian menutup aurat dengan syar'i. Maka tidak menutup kemungkinan bahwa muslimah tersebut akan tertarik dengan produk fashion hijab yang akan dipasarkan dalam kegiatan PKK tersebut, kemudian setelah membeli dan menggunakan produk tersebut diharapkan merekomendasikan kepada orang lain. Dengan model pemasaran tersebut kita mendapatkan dua keuntungan. Keuntungan yang pertama adalah memperoleh laba dari produk yang dipasarkan dan telah laku, keuntungan kedua ialah terbentuknya jaringan- jaringan pemasaran baru akibat dari referal yang dilakukan oleh customer.

Menurut Hasan (2010:9) Jika silaturahmi marketing ini terus berkembang secara sustainable, maka akan berdampak positif bagi local wisdom di dalam masyarakat. Hal tersebut merupakan pengaruh dari local wisdom yang mempunyai ciri-ciri sebagai berikut:

1. Merupakan bentuk warisan peradaban yang akan dilakukan terus menerus dari generasi ke generasi

2. Mampu mengendalikan pengaruh dari luar

3. Menyangkut nilai dan moral masyarakat setempat

4. Tidak tertulis, tetapi diakui sebagai kekayaan dalam berbagai segi pandang hukum

5. Merupakan bentuk sifat yang melekat pada seseorang berdasarkan asalnya. 


\section{Kesimpulan}

Budaya Indonesia sangat lekat dengan budaya-budaya daerah atau yang lebih dikenal dengan sebutan adat istiadat. Antara daerah yang satu dengan daerah yang lain memiliki ciri khas budaya yang berbeda. Desakan arus globalisasi dan digitalisasi pada era sekarang ini perlu untuk dibatasi supaya tidak mengalir deras mengikis peradaban bangsa yang sudah lama melekat di dalam kehidupan masyarakat. Keaneragaman budaya bangsa perlu dilestarikan keberadaannya dan keberlangsungannya, karena budaya merupakan salah satu simbul kekayaan bangsa ini, sehingga diperlukan adanya sebuah strategi maupun pendekatan pemasaran yang efektif,pendekatan pemasaran yang ramah dengan budaya/ kearifan lokal baik bagi penjual maupun pembeli tanpa merusak local wisdom di dalam masyarakat.

Local wisdom adalah nilai yang dianggap baik dan benar yang berlangsung secara turun-temurun dan dilaksanakan oleh masyarakat yang bersangkutan sebagai akibat dari adanya interaksi antara manusia dengan lingkungannya. Pendekatan pemasaran yang sesuai dengan local wisdom/kearifan lokal bangsa Indonesia adalah pendekatan pemasaran dengan silahturahmi marketing.

Silaturahmi marketing adalah suatu strategi pemasaran (marketing) yang dilakukan oleh penjual dengan tujuan untuk menyambung ikatan persaudaraan, baik ikatan yang sudah terjalin maupun ikatan yang belum terjalin. Silaturahmi marketing ini akan meningkatkan kembali jiwa sosialisme manusia yang kian terkikis oleh perkembangan zaman, akibat dari era globalisasi yang membuat dunia seakan-akan berada dalam gengaman. Jiwa sosialisme ini yang selanjutnya akan meningkatkan local wisdom dalam suatu masyarakat. Pemasaran dengan menggunakan model silahturahmi marketing mendatangkan berbagai keuntungan selain keuntungan memperoleh laba juga pebisnis akan terbentuk jaringanjaringan pemasaran baru yang merupakan hasil referensi dari customer. 


\section{Daftar Pustaka}

Abdulah,Amri,2007. Strategi Pemasaran Asuransi Syariah.Jakarta:Grasindo.

Agus Maladi Irianto, "Komodifikasi Budaya di Era Ekonomi Global Terhadap Kearifan Lokal" Volume 27 No 1, Juni 2016, Hlm. 214

Apriyanto,Y.dkk.2008. Kearifan Lokal Dalam Mewujudkan Pengelolaan Sumberdaya Air Yang Berkelanjutan.Makalah Pada IKM IPB,Bogor.

Assauri, Sofjan.2013. Manajemen Pemasaran. Jakarta: Rajawali Pers

Al arif, M. Nur Rianto .2012 Dasar-dasar Pemasaran Bank Syariah.Bandung: Penerbit Alfabeta.

Buchari Alma,2011. Manajemen Pemasaran dan Pemasaran Jasa. Bandung: Alfabeta

Gartika, Gagan.2013. Silaturahmi Marketing, Jakarta: PT Gramedia Pustaka Utama

Hasan, Ali.2010.Marketing Bank Syariah.Bogor: Penerbit Ghalia Indonesia

Hermawan Kertajaya, Muhammad Syakir Sula.Syariah Marketing. Bandung: Mizan Pustaka

Kasmir.2004. Pemasaran Bank. Jakarta: Prenada Media Grup

Keraf,A.S.2010.Etika Lingkungan Hidup.Jakarta: Penerbit Buku Kompas

Kottler dan Keller.2012.Marketing Management Edisi 14.Global Edition.Pearson Prentice Hall

Rivai, Veithzal. 2011.Islamic Marketing, Jakarta: PT Gramedia Pustaka Utama,

Ridwan, N.A. 2007. Landasan Keilmuan Kearifan Lokal. Jurnal Studi Islam dan Budaya. Vol.5,(1),27-38

Sofjan Assauri.2013. Manajemen Pemasaran,Jakarta:Rajawali Pers

Shinta Prastyanti, "Kearifan Lokal Di Era Global”, diakses dari http://komunikasi.unsoed.ac.id/sites/default/files/56.shinta-unsoed.pdf, pada 5 November 2017 pukul : 09.45 WIB, hlm. 782

Thorik Gunara, Utus Hardiono Suddibyo.2007. Marketing Muhammad. Bandung: PT Karya Cipta 